\title{
CHRISTIANITY FROM THE MARGINS IN SOUTHEAST ASIA
}

\author{
Jose Mario C. Francisco \\ Ateneo de Manila University \\ mariofrancisco49@gmail.com \\ Shanthini Pillai \\ National University of Malaysia \\ spillai@ukm.edu.my
}

\begin{abstract}
Studies on Christianity in Asia have been weighed down by a double burden-the commonplace of Christianity as a passive minority and an invading foreign as well as the notions of religion and secularization derived from western experience. The following essays of Forum Kritika shed both burdens by focusing on the "lived religion" of different Christian groups and leaders on the margins of Southeast Asian societies because of religious faith as well as ethnicity, status or location. Their critical analysis shows how these actors interacted with other social and cultural traditions and problematized narratives of identity linked to the dominant sociocultural ethos. These negotiations, far from being private and divorced from the institutional, point to the complex and dynamic nature of Christianity in the Asian landscape and to how Christian groups and individuals manage to hold their ground.
\end{abstract}

\section{Keywords}

Catholicism, cosmopolitan, ethnicity, indigenous, lived religion, nation, Southeast Asia

\begin{abstract}
About the Authors
Jose Mario C. Francisco is a Filipino Jesuit professor at Loyola School of Theology, Ateneo de Manila University, and the Pontificia Università Gregoriana, Rome, Italy. He has taught at Boston College as Gasson Professor, Jesuit School of Theology at Santa Clara University, and East Asian Pastoral Institute. His teaching and research focus on religious and cultural studies in Asian contexts. He published critical editions of seventeenth-century Philippine manuscripts and edited anthologies on Asian theology. His recent essay, "Migration and New Cosmopolitanism in Asian Christianity," is included in The Oxford Handbook on Christianity in Asia (2014). Other essays appeared in The Cambridge History of Christianity, Christianities in Asia, Dictionary of Christianity in Asia and in international journals.
\end{abstract}


Shanthini Pillai, Ph.D is Associate Professor at the Faculty of Social Sciences and Humanities, National University of Malaysia (UKM). Her research interests are anchored primarily in ethnic diversity, diaspora and transnationalism in literary and cultural texts with particular reference to the global South Asian diaspora. An emergent interest is in the cultural consciousness of Catholic diasporic Indians in Malaysia. She is author of Colonial Visions, Postcolonial Revisions: Images of the Indian diaspora of Malaysia (2007) as well as numerous articles in various journals of Literary and Cultural Studies. She is also a recipient of the 2006-2007 Australia-Malaysia Institute Fellowship, as well as the 2013 Asia Research Institute Visiting Senior Fellowship. 
Typically characterized as minority and foreign, Christianity is "one of the largest and fastest-growing religions in Asia" and has thus elicited much scholarly interest (Bautista and Lim, Christianity and the State 1). Earlier studies, often from an explicit or implicit Christian perspective (e.g., Phan, Christianities in Asia), concentrated on institutional practices, beliefs and symbols or on power relations between Christian evangelism and local networks of imperial governance and colonial domination. Among issues discussed were conversion controversies with other religious traditions, disputes with various authorities, destruction of local cultural practices and the alienation of the converted (e.g., Young, Resistant Hinduism and "Empire and Misinformation;" Viswanathan, Outside the Fold).

However, more recent studies shifted the emphasis away from the institutional and the dominant power-relations into, for instance, the creative integration of Christian elements into native schemata by both missionaries as well as early converts among the local population (e.g., Steenbrink, Catholics in Indonesia; Frykenberg, Christianity in India). Thus they bring to greater focus the complex and dynamic nature of religious traditions in the Asian landscape, notably those with highly differentiated institutions and communities like Catholicism. Most notable among these studies is the Oxford Handbook on Christianity in Asia that aims to be "a first comprehensive mapping of the current state of Christianity in Asia" with an interdisciplinary approach "applying the analytical and hermeneutical tools of history, religious studies, and the social sciences" (Wilfred, Oxford Handbook of Christianity in Asia 3). Like the Handbook, these later studies acknowledge the plurality of Christianity in Asia and focus on the impact of "the interaction and social processes in the encounter between Christianity and sociocultural contexts" (Wilfred 5).

\section{THEORETICAL OVERVIEW ON “EVERYDAY CHRISTIANITY”}

Sharing this same theoretical and methodological perspective, this Forum Kritika of seven essays - two on Singapore and one each on Thailand, Vietnam, Indonesia, Malaysia and the Philippines-points to theoretical and empirical nuances in the dynamic negotiations between Christianity and nations in Southeast Asia. Whereas Bautista and Lim's anthology concentrates on "how the state has either hindered or facilitated the propagation, regulation or maintenance of the Christian faith" (1), these essays do not only investigate Christianity's interaction with the nation-state as "an imagined political community" according to Benedict Anderson (6) but also with "nations-of-intent" described by Malaysian social scientist Shamsul A.B. as "[a group's] own vision of what the national identity should be" ("Nations-of-Intent" 31). Given this wider understanding of nation, they turn their sights on particular constituencies on the margins and thus problematize reigning narratives tied to religion, nation, ethnicity and other social markers. 
Moreover, this focus on marginalized constituencies avoids the traditional perspective on Christianity in terms of its authoritative texts, normative traditions and official church discourses, a perspective often borne out of notions of religion from "western" discourse (21-66). It discusses what Meredith McGuire calls "lived religion: faith and practice in everyday life." Thus the essays analyze the "lived Christianity" of an indigenous community or of devotees in urban space, of individuals facing dominant religious traditions or of young professionals and economic migrants in a cosmopolitan city, and explore how they place themselves within the intricate interstices of their sociocultural contexts.

At the same time, the essays do not see these negotiations by groups or individuals as isolated or private, thus undermining what is often referred to as moments of secularization-the decline and privation of religion and the differentiation of social realms (Casanova 19-39). They indicate how these negotiations engage institutional Christianity, other religious and social traditions, and the social networks each tradition is bound to. Such negotiations, however, are not a modern, even post-modern, invention. As recent studies in medieval religious practice show, individuals and groups negotiated their own ways even when Christendom held its greatest sway (e.g., Bynum, Christian Materiality).

Furthermore, globalizing forces of communications technology as well as movements of peoples and resources do not threaten, but intensify, such negotiations (Beyer and Beaman, Religion, Globalization and Culture). In their critical analysis of particular negotiations, the essays in this Forum Kritika interrogate the commonplace of Christianity in Southeast Asia as a passive minority and an invading foreign. Though constituting a minority in number except in the Philippines and Timor Leste and considered foreign because of early missionary and colonial movements, Christianity manages to hold ground within the Southeast Asian landscape.

\section{ZOOMING IN ON THE SEVEN ESSAYS}

All the essays in this forum engage negotiations between Christianity and the dominant sociocultural ethos along the margins. Their specific contributions relate to the locations of the particular constituency each essay explores and the nature of the dominant sociocultural ethos encountered. Three essays look back into the historical roots of these negotiations. Focusing on Catholicism in Indonesia, Albertus Bagus Laksana shows how its "universal ecumenism" or what would be more recently referred to as its transnational character helped to expose the severe limitations of Dutch colonial authority and to inculcate an acute awareness of individual dignity. Central to his discussion is the figure of Albertus Soegijapranata, 
a Javanese Jesuit and Indonesia's first native bishop, born in Muntilan, the birthplace of Javanese Catholicism known as "Bethlehem van Java." Laksana highlights in turn how Dutch Jesuit missionary education provided a space for religio-cultural negotiations and eventually contributed to hybrid nationalism and the gradual acceptance of the Catholic community in the larger national narrative.

In a similar vein, Hung Pham insightfully presents a historical exploration of the Vietnamese encounter with Christianity. He initially describes the intense resistance Christian converts experienced as they embraced the new faith, and then points to Jesuit missionary efforts to translate Christian texts, the most significant of which was replacing the Chinese script with what would become the modern Vietnamese script. This act of alphabetization of native language, commonly used by European missionaries to facilitate evangelization from the $16^{\text {th }}$ century onwards, won over the hearts of the Vietnamese elite, and subsequently gave rise to Vietnamese Christian literature consisting of the reinterpretation of biblical stories in Vietnamese contexts. The concluding section of Pham's essay is a close-up of Hàn Mặc Tử, a modern Vietnamese poet who skillfully expressed JudeoChristian beliefs and concepts of transcendence and immanence through iconic symbolism and imagery from traditional Vietnamese history and the Confucian ethos. This successful interweaving of the Christian with the Vietnamese led to the recognition of Han's writings as an integral part of Vietnamese modern poetry included in the Vietnamese school curriculum and as testimony of its acceptance into the sociocultural ethos of mainstream society.

In her essay on Christianity in Thailand, Coeli Barry takes a slightly different tone in offering an alternative angle into what has often been seen as the unobstructed journey of Christian mission there. She uncovers certain ruptures in the accepted narrative by calling attention to confrontations with the Western Christian as an unwelcome Other, merely tolerated and not embraced willingly into the national fold. Discursive battles between Buddhist national apologetics and the minority Catholic community are discussed. But just as Laksana's essay points out in the Indonesian context, Christianity's involvement in education and social action programs prove to be vital and contributing elements to the modernization of Thailand. Thus Barry's essay is important for its "refracted view of the Thai 'national' imagination," and together with those of Laksana and Pham, traces historical roots of negotiations between Christianity and nation in Southeast Asia today.

Thefollowingessaysconcentrate on ongoing negotiationsinvolvingconstituencies from the margins in other parts of the region. Jojo Fung's essay extrapolates the immeasurable complexities surrounding Christians and Christianity in modern day Malaysia with special focus on East Malaysia. Referring to these complexities as "multiple fault lines," Fung shows how the recent legal controversy over the 
right of Christians to use the word "Allah" for God exposed the "intricate interplay and asymmetrical relations between the dominant 'fictitious self' and subjugated 'fragmented self' of the minority ethnic and religious communities." He then demonstrates how indigenous communities in East Malaysia in turn negotiate their continued survival through a "reconciliatory praxis" that combines diverse religious and local traditions with steadfast rootedness in Christian foundations. Through the strategy of "multiple participations," these communities weave ameliorative narratives that allow them to stand their ground amidst the fictitious grand narrative of national unity.

Mark Calano's essay on the Philippines initially appears not to be "from the margins" as it focuses on the Black Nazarene devotion popular among the dominant Catholic majority. However, its exploration takes place in Quiapo, Manila - the margins of the modernized Filipino urban landscape symbolized by Makati and the Bonifacio Global City. In line with recent studies such as those from the 2014 Philippine Studies issue on Filipino Catholicism that explore traditional Catholicism's negotiations with contemporary social forces, Calano examines the interweaving of traditional indigenous beliefs with Christian precepts as a strategy to deal with the Philippine nation state. This interweaving in religious performances of Quiapo devotees carry significant implications for the construction of urban space-offering a sense of familial connection across social class and status, and even exploiting weaknesses in the official narrative of Philippine nationhood.

The last two essays look at constituencies in the cosmopolitan city-state of Singapore-young adults and transient migrants respectively. In the former, Cornelio explores the aspect of aspiration among young adult Christians through the lens of the capacity to be content. He discusses three thematic threads central to the nation state- - "the pursuit of happiness, the questioning of Singapore's incessant drive for economic growth, and the neglect of the left-behind" - and discovers that these young adults measure aspirations in terms not only of upward social mobility but also of gaining Christian moral ground through their participation in welfare activities and social work. For them, this constitutes a middle ground between their religious practice and the accepted ethos in Singapore "where religion and politics do not mix."

The essay of Catherine Gomes and Jonathan Tan explores the ways in which Christianity becomes a pillar of strength for Singapore's vast transient migrant communities. Based on quantitative and qualitative research on international students and working professionals, they indicate how Christianity provides a pathway towards a sense of belonging in an otherwise transitory existence and an antidote to the larger discriminatory experiences they face as transient migrants on the margins of mainstream Singaporean society. This consequently offers them 
the agency with which to construct and reconstruct their own Christian identity with a sense of being at home in a foreign land.

This Forum Kritika of seven essays then offers some insights into the dynamic encounter between Christianity and nation in contemporary Southeast Asia. Its limitations include the absence of essays on other countries in the region, especially the majority-Catholic Timor Leste, as well as the unintended focus on Catholicism, which was often the first bearer of Christianity in Southeast Asia. They do not allow comparative perspectives between national contexts and transnational considerations of Christianity across borders.

Nevertheless, the forum serves to highlight the encounter between Catholicism in the margins and the various articulations of nation dominant in the region. This encounter shows how communities and individuals belonging to a minority religious tradition typically considered foreign are empowered to construct their niche within or even against the wider and official social fabric. In problematizing the typical construction of Christianity in Asia as minority with no agency and as foreign without local roots, the forum echoes the contemporary discourse on religious traditions as transnational and globalizing forces with porous borders and shifting grounds. 


\section{Works Cited}

Anderson, Benedict. Imagined Communities: Reflections on the Origin and Spread of Nationalism. Revised edition. Pasig City: Anvil, 1991. Print.

Asad, Talal. Formations of the Secular: Christianity, Islam, Modernity. Stanford: Stanford UP, 2003. Print.

Bautista, Julius and Francis Ghek Kee Lim, eds. Christianity and the State in Asia: Complicity and Conflict. London: Routledge, 2009. Print.

Beyer, Peter and Lori G. Beaman, eds. Religion, Globalization and Culture. Leiden: Brill, 2007. Print.

Bynum, Caroline Walker. Christian Materiality: An Essay on Religion in Late Medieval Europe. New York: Zone Books, 2011. Print.

Casanova, Jose. Public Religions in the Modern World. Chicago: U of Chicago P, 1994. Print.

"Filipino Catholicism." Philippine Studies: Historical and Ethnographic Viewpoints 62.3-4. (2014). Print.

Frykenberg, Robert Eric. Christianity in India. New York: Oxford UP, 20o8. Print.

McGuire, Meredith B. Lived Religion: Faith and Practice in Everyday Life. Oxford: Oxford UP, 2008. Print.

Phan, Peter C., ed. Christianities in Asia. West Sussex: Wiley-Blackwell, 2011. Print.

Steenbrink, Karel. Catholics in Indonesia, 1808-1942: A Documented History. Volume 2: The Spectacular Growth of a Self Confident Minority, 1903-1942. Vol. 2. Leiden: Brill, 2007. Print.

Shamsul A.B. "Nations-of-intent in Malaysia." Shamsul A.B.: His Observations, Analyses\& Thoughts. Ed. Anis Yusal Yusoff. Bangi: Institute of Ethnic Studies (KITA), Universiti Kebangsaan Malaysia. 31-50. Print.

Viswanathan, Gauri. Outside the Fold: Conversion, Modernity, and Belief. New Jersey: Princeton UP, 1998. Print. 
Wilfred, Felix, ed. The Oxford Handbook of Christianity in Asia. Oxford: Oxford UP, 2015. Print.

Young, Richard Fox. Resistant Hinduism: Sanskrit Sources on Anti-Christian Apologetics in Early Nineteenth-Century India. Vol. 8. Leiden: Brill, 1981. Print.

--- "Empire and Misinformation: Christianity and Colonial Knowledge from a South Indian Hindu Perspective (ca. 1804)." India and the Indianness of Christianity: Essays on Understanding-Historical, Theological, and Bibliographical-in Honor of Robert Eric Frykenberg, Studies in the History of Christian Missions. Ed. Richard Fox Young. Grand Rapids: Eerdmans, 2009. 59-81. Print.

Yusoff, Anis Yusal, ed. Shamsul A.B.: His Observations, Analyses and Thoughts. Kuala Lumpur: Universiti Kebangsaan Malaysia, 2010. Print. 